Saudi Journal of Business and Management Studies Abbreviated Key Title: Saudi J Bus Manag Stud ISSN 2415-6663 (Print) |ISSN 2415-6671 (Online) Scholars Middle East Publishers, Dubai, United Arab Emirates Journal homepage: https://saudijournals.com

\title{
The Effect of Current Earnings, Operating Cash Flows and Accrual Quality on Future Earnings (Empirical Study on Manufacturing Companies Listed on The Indonesia Stock Exchange Year 2016 - 2018)
}

\author{
Nanda Thaliana Raditya ${ }^{1 *}$, Wiwik Utami ${ }^{2}$ \\ ${ }^{1,2}$ Department of Accounting Mercu Buana University, Indonesia
}

DOI: $10.36348 /$ sjbms.2021.v06i04.003 $\quad$ Received: 14.02 .2021 | Accepted: 26.03 .2021 | Published: 07.04 .2021

*Corresponding author: Nanda Thaliana Raditya

\section{Abstract}

This study aims to determine the effect of current earnings, operating cash flow and accrual quality on future earnings. The population of this research is manufacturing companies listed on the Indonesia Stock Exchange for the period 20162018. The sample used purposive sampling and obtained a sample of 100 companies with a time period of 3 years to obtain 300. Earnings are proxied by net earnings after tax which is scaled to total assets or Return on Asset, Accrual quality is proxied by discretionary accruals of working capital, Future earnings are earnings. In the period $t+1$. The research method concludes that there is a positive and significant effect of current earnings and operating cash flows on future earnings, while accrual quality has no effect on future earnings.

Keywords: Current Earnings, Operating Cash Flow, Accrual Quality, Future Earnings.

Copyright (C) 2021 The Author(s): This is an open-access article distributed under the terms of the Creative Commons Attribution 4.0 International License (CC BY-NC 4.0) which permits unrestricted use, distribution, and reproduction in any medium for non-commercial use provided the original author and source are credited.

\section{INTRODUCTION}

The information contained in the financial statements of a company is important information for its users in making economic decisions. The ability of economic actors to predict the financial condition of a company in the future is needed before making economic decisions. The development of a company's financial condition can be seen from its performance. The better the performance of a company, the better the financial condition of a company. The financial condition of a company can be seen from the size of the company's operating cash flow [1]. This information is used as a basis for predicting the future conditions of the company and making economic decisions.
Based on the objective of financial reports, which is to provide useful information for assessing the prospects for cash flow, a cash flow statement is required. Prayoga [2] also explains that in predicting company conditions in the future, economic actors need historical data in financial reports that can help predict this. One of the financial reports that can be used as consideration in making economic decisions is a cash flow statement. This shows that the performance appraisal of a company is not only focused on the income statement and balance sheet. The mistake that often occurs is the assumption that if revenue and profit increase or increase well, the company's performance will also shine. These assumptions will sometimes trap our thinking in assessing the performance of a company. 


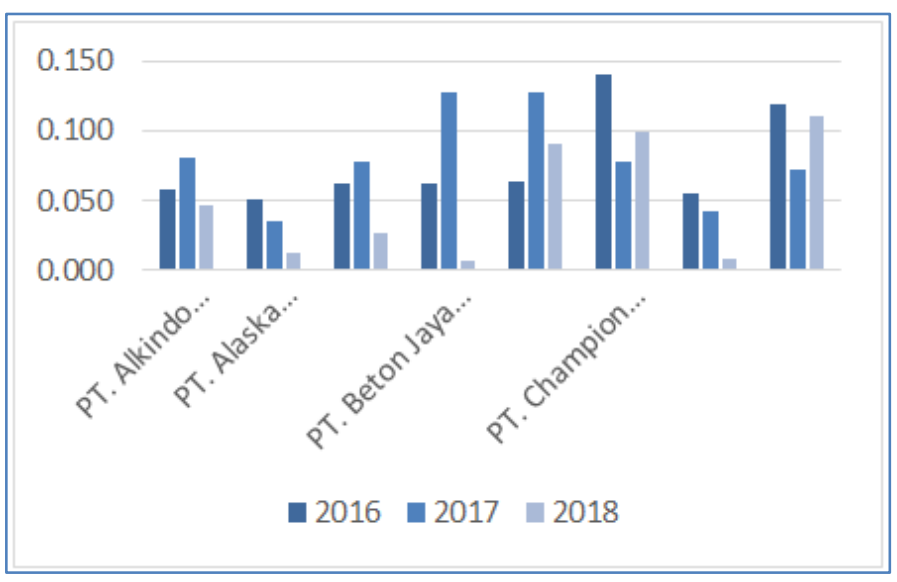

Fig-1: Issuer's Profit Chart for the 2016-2018 Period

Based on data taken from samples of financial statements of several manufacturing companies listed on the Indonesia Stock Exchange for the period 20162018 [39], several companies generated unstable (fluctuating) profit. Companies with quality earnings conditions were influenced by several factors including internal and external factors. Internal where internal factors are the characteristics of top management who are the parties who compile and are fully responsible for the financial statements published by a company. Boediono [3] says that the characteristics of top management have a major effect on earnings disclosure, so that it can attract investors and shareholders' confidence. This has an impact on the survival of the company, so the company needs to pay attention to how the condition of the company's profits in the future. According to Wiwik [4], earnings management can perform financial reporting that can produce income smoothing or profit maximization and profit decline so that it can affect the level of dividends that investors will receive.

According to the Ikatan Akuntansi Indonesia [5], in the conceptual framework of financial statements, profit is defined as an increase in economic benefits during a particular accounting period in the form of income and addition of assets or a decrease in liabilities that results in an increase in equity, which does not come from investment contributions. The importance of earnings information and assessing management performance also helps estimate the ability of presentative earnings and assess risks in investment or credit.

In Al-Attar and Maali's [6] research, the components of earnings are assessed based on their quality. The results of the study found that earnings quality influences predicting future earnings. When earnings quality is high, both cash flow and earnings have the same ability to predict future earnings.

Operating cash flows represent the company's main revenue-producing activities and other activities that are not investing and financing activities according to accounting standards No. 2 of 2020. Operating cash flow can be used as the primary indicator in determining whether the entity's operations can generate. Sufficient cash flow to borrow, maintain the entity's operating ability, pay dividends, and make new investments without relying on outside sources of income and helps predict future earnings

Accrual quality is the quality of accounting information presented by a company that compares its accruals to cash flows in the past, present, and future [7]. Accrual quality is good if the accruals are close to the company's future cash flows [8]. Accrual quality has a higher level of relevance as a measurement proxy because earnings compiled on an accrual basis indicate the economic implications and existing transaction events.

Based on the description above, the authors are interested in researching with the title: "The Effect of Current Earnings, Operating Cash Flow, and Accrual Quality on Future Earnings in Manufacturing Companies"

\section{LITERATURE REVIEW Signaling Theory}

Signal theory discusses information provided by a company about its future performance that outsiders will trust. This theory emphasizes the importance of information issued by companies regarding investment decisions to be taken by investors. According to Jogiyanto [9], companies' information is an announcement that gives a signal for investors to make investment decisions. This announcement contains both positive and negative information that can cause market reactions.

The relationship between signal theory and current earnings, operating cash flow, and accrual quality in predicting future earnings can provide information in the form of operating cash flow reports that can provide information issued by companies regarding investment decisions. Information is essential for investors and business people because it provides 
Nanda Thaliana Raditya \& Wiwik Utami., Saudi J Bus Manag Stud, Apr, 2021; 6(4): 125-134

records and descriptions of the past, present, and future for companies and the capital market. Capital market investors need complete, relevant, accurate, and timely information as an analytical tool before deciding to invest. Information published as an announcement will serve as a signal for investors in making investment decisions. If the announcement contains a positive value, it is expected that the market will react when the market receives it. When information is announced and market participants have received the information, market participants first interpret and analyze the information as a good signal or a wrong signal. If the announcement is announced as a good signal for investors, there will be changes in share trading volume [10].

\section{Agency Theory}

Jensen and Meckling [11] describe agency relationships as follows: "Agency relationship as a contract under which one or more person (the principals) engages another person (the agent) to perform some service on their behalf which involves delegating some decision making authority to the agent."

The relationship between agency theory and current earnings, operating cash flow, and accrual quality in predicting future earnings is significant for its users. Every company is competing to increase earnings which cause company management to report unreal earnings (earnings management). Earnings management is carried out in preparing financial statements to influence the level of earnings shown so that it is expected to increase the value of the company at a particular time. Performance engineering, known as earnings management, is in line with agency theory, emphasizing the importance of company owners leaving company management to professionals (agents) who better understand and understand how to run a business.

This condition occurs because of information asymmetry between management and other parties who do not have adequate sources and access to information used to monitor management actions. Management has complete and detailed information about the company and has more flexibility in influencing financial reports (especially earnings) than shareholders.

\section{Future Earnings}

Information about earnings is a good indicator to determine or assess the company's ability to generate cash in the future [12]. According to Santoso [13], the measure of net income is used by investors and creditors to evaluate a company's ability to generate earnings (earnings ability). Radiation (2010: states that earnings figures can provide information as a tool to estimate and estimate cash flow for dividend distribution and as a tool to obtain the strength and value of the company in the future by using proxies to measure earnings. Next year. Future gains are measured using revenue $t+1$ scaled against total assets $t+1$

\section{Current Earnings}

Every company strives for maximum earnings. Earnings obtained by the company will affect the survival of the company in achieving its goals. Subrahmanyam and John [14] state that earnings or net income show its profitability. Earnings reflect the return to equity holders for the period, while the items in the report detail how that profit was made. The net earnings figure is a number that shows the difference between all revenue from the company's operating activities and the company's non-operating activities. Earnings can be measured using a proxy for net income after tax divided by total assets. Earnings are also a return on investment for the owner and show how management successfully runs the business. This shows how much the company's assets are used effectively to generate earnings, and the greater the ROA shows, the better performance, because the rate of return is more significant so that the value that the entity can give to investors is in the form of dividends if the entity still has the same wealth in its position early [15]. According to Rieke [16], management practices are mainly carried out by management because they think other companies are also doing the same thing.

\section{Operating Cash Flow}

Operating activities are the main revenueproducing activities of the company and other activities that are not investment activities and financing activities according to accounting standards No. 2 of 2020. Operating cash flow can be used as a primary indicator in determining whether the entity's operations can generate sufficient cash flow to be used for loans, maintain the entity's operating ability, pay dividends, and make new investments without relying on outside sources of income and help predict future cash flows.

\section{Accrual Quality}

Dechow et al. [17] define high earnings quality as those that more honestly represent features of the company's fundamental earnings process that are relevant to specific decisions made by decision-makers. Many attributes can be used to measure earnings quality, including accruals quality, persistence, predictability, smoothness, value relevance, timeliness, and conservatism $[18,17,19]$. This study will focus on assessing earnings quality by using accruals quality as a proxy.

Accrual quality is the quality of accounting information presented by a company that compares accruals to company cash flows in the past, present, and future periods [7]. Accrual quality is good if the accruals are close to the company's future cash flows [8]. Accrual quality has a higher level of relevance as a measurement proxy because earnings that are compiled 
on an accrual basis are more indicative of the economic implications and existing transaction events.

This model was developed by Dechow and Dichev [8] because it seems that there is a relationship between realized cash flows and working capital, so that the accrual to cash flow matching function is essential. The accrual model with Working Capital Accrual (WCA) is created as a function of past (CFOt-1), present $(\mathrm{CFO})$, and future $(\mathrm{CFOt}+1)$ cash flows because accruals can anticipate the cash to be received/paid and reversed when cash previously recorded as accruals received/paid. The standard deviation of the error (et) is a proxy for earnings quality, with the higher the error value, the lower the accrual quality. McNichols [20] then modified the model from Dechow and Dichev [8] by combining it with the Jones [21] model and dividing accruals into discretionary accruals and non-discretionary accruals. As a result, McNichols [20] found an increase in the power of explanation.

\section{WCA $=a+b 1 C F O t \_1+b 2 C F O t+b 3 C F O t+1+b 4 \Delta R e v+$ b5PPEt+et}

\section{HYPOTHESIS}

(Paragraph 7), accounting earnings are the net earnings or loss for the period after deducting tax expense. The two main processes of measuring earnings are revenue recognition and expense. Revenue recognition is the starting point for measuring revenue. According to Keiso [22], net income is the earnings earned after deducting taxes. These earnings are the earnings obtained from the difference between income and expenses that taxes have deducted in more detail. Also, some call it earnings before interest, taxes, and depreciation. Earnings are a recurring component in any income statement formation. The information held in the income statement can assess the uncertainty of future cash flows because it can show the company's performance during the current year. This information is also a signal for investors to make decisions. The amount of profit received is reflected in the amount of cash received from sales activities fewer expenses. The earnings that will be used in dividend payments will be determined from historical information and its amount of profit. Martini's research [23] concluded that current earnings have a positive effect on future earnings. This is also supported by Yuwana [24] and Kusuma [25], which state that earnings can predict future earnings. The greater the company's net earnings, the greater the company's cash receipts in the future.

\section{H1: Current earnings affect future earnings}

Cash flows originating from operating activities originating from the company's main activities are recurring and continuous, allowing cash flows from operating activities to reflect a large part of the continuation of cash inflows or cash flows from the company's operational activities in the following period [26]. Operating activities are indicators that determine whether the company's operations can generate cash that can be used to pay off loans, maintain the company's operating capability, pay dividends and make new investments without relying on outside funding sources. So that operating cash flow can be a signal to investors regarding the condition of the company. Yuliafitri's research [27] concluded that cash flow has a positive effect on future earnings. This is also supported by research by Mulenga and Bhatia [6] in their research, which reveals that operating cash flow can predict future earnings.

\section{H2: Operating cash flows affect future earnings}

Accrual quality can provide a signal to users of financial statements, especially investors, in making decisions. These signals can be in the form of information contained in financial statements. This information is expected to assist investors in making investment decisions. The accrual quality concept recognizes a transaction, especially income and expenses when it occurs without being linked to a cash transaction. The accrual basis's determination is also based on legal factors, whether it is the rights and obligations of the company or not. The accrual basis will include recording transactions in the past and various rights and obligations in the future. Naina's research [28] concluded that accrual quality has a significant effect on future operating income. It is also supported by research by Arnedo, Lizarraga, and Sánchez [29], which states that accruals have a better ability than current cash flows in predicting future cash flows.

\section{H3: Operating cash flows affect future earnings}

\section{RESEARCH METHODS}

This research was conducted by collecting data obtained through manufacturing companies on the Indonesia Stock Exchange or downloading financial report data through www.IDX.co.id. This type of research is a type of quantitative research. According to Pardede and Manurung [30], quantitative research is a study that uses numbers as a research approach. The type of data used in this study is secondary data (secondary sources). Sekaran and Bougie [31] explain secondary data is referenced in the information collected through several existing sources. This study aims to analyze the effect of independent variables, namely: earnings as (X1), operating cash flow as (X2), and accrual quality as (X3) on the dependent variable, namely future earnings as $(\mathrm{Y})$. 
Nanda Thaliana Raditya \& Wiwik Utami., Saudi J Bus Manag Stud, Apr, 2021; 6(4): 125-134

\section{RESULTS AND DISCUSSION}

Table-1: Descriptive Statistics Test

\begin{tabular}{|l|c|c|c|c|r|}
\hline \multicolumn{7}{|c|}{ Descriptive Statistics } \\
\hline & \multicolumn{1}{|c|}{ N } & Min & Max & Mean & Std. Deviation \\
\hline Current Earnings & 300 &,- 548 &, 527 &, 04928 &, 103918 \\
\hline OCF t & 300 &, 000 &, 964 &, 08553 &, 124301 \\
\hline Accrual & 300 &, 001 & 2,129 &, 14513 &, 152442 \\
\hline Income & 300 &,- 401 &, 921 &, 04713 &, 112637 \\
\hline Valid N (listwise) & 300 & & & & \\
\hline
\end{tabular}

(Source: Data processed by SPSS 20, 2020)

a. Based on the calculation results in table 1 shows descriptive statistics of variables used in the study with the amount of data per variable is 300 as follows:

b. There are $300(\mathrm{~N})$ studies that fall into the category of manufacturing companies listed on the Indonesia Stock Exchange for three consecutive years consisting ofc, operating cash flow, accrual quality to future earnings. The measurement of descriptive statistics shows that calculating the current earnings as measured by ROA has an average value of 0.04928 and a standard deviation value of 0.103918 . This value shows that the average net profit for the 20162018 period is low. The minimum value of assets can generate profits of -0.548 or $54.8 \%$ is found in 2016, but in 2018 experienced a significant increase of $5.3 \%$. Companies that experience losses are also included in this study to determine how much influence current earnings have in predicting future earnings. These proves that the more current corporate earnings, the greater the company's earnings in the future.

c. Operating cash flow is an indicator that determines whether the company's operations can generate sufficient cash flow to pay off loans, maintain the company's operating ability, pay dividends, and make new investments without relying on outside funding sources, as seen in the following table 1 . Have a minimum value. Which was obtained from operating cash flow to total assets in 2017 resulted in an operating cash flow of 0,000 contained, Then in 2016 to 2017 there was an increase of $0.04 \%$, this increase in operating cash flow can attract various parties such as investors and creditors, which indicates that the company can generate sufficient cash flow to pay off loans, maintain operating capability company. Pay dividends and make new investments without relying on outside funding. Meanwhile, companies that have a maximum operating cash flow value obtained from operating cash flow to total assets, namely 0.964, are found in 2017, although it decreased in 2018 by $0.5 \%$ of operating cash flow for the current period, it can still be used as a predictor in predicting future profits. Meanwhile, the average operating cash flow value is 0.08553 with a standard deviation of 0.124301 . This value indicates that the average operating cash flow value is quite good. Future operating cash flows help investors and creditors see how they can pay dividends and repay loans to creditors. If a company's operating cash flow outlook improves consistently, it can attract investors and creditors.

d. Accrual quality contained in table 1 is a company that has the lowest accrual quality value. In 2016 has a minimum value of 0.001 ; the lower the absolute value of the accrual quality residuals, the better the accrual value. The accrual value is obtained from the error value in the WCA (Working Capital Accrual) formula. The error value is obtained from the rest of the WCA regression equation, and then the value is absolute. The lower the error value, the better the accrual quality. Meanwhile, the company with the highest accrual quality value in 2017 has a maximum accrual quality value of 2,129 . The average value obtained is 0.14513 with a standard deviation of 0.152442 . Accrual quality is said to be good if accruals have closeness to the company's future cash flows. Accruals' quality has a higher level as a proxy for measurement because accruals are prepared to show more economic implications and existing transaction events. Besides predicting future cash flows, accrual quality can also e used to predict future earnings.

e. Future earnings have an average value of 0.04713 and a standard deviation of 0.112637 . It means that the average value is smaller than the standard deviation, thus indicating unfavorable results because the standard deviation $\mathrm{s}$ a reflection of a very high deviation. The lowest future profits were found in 2018 amounted to $-0,401$ or $40.1 \%$, while the highest future profit value was found in 2017 amounted to 0.921 , in 2018 it decreased by $8.7 \%$, this is because future earnings figures can provide information as a tool to estimate and estimate cash flow for dividend distribution, and as a tool to generate power and future value of the company. 
Table-2: Normality test

\begin{tabular}{|l|l|}
\hline \multicolumn{2}{|c|}{ Runs Test } \\
\hline Test Value $^{\mathrm{a}}$ & Unstandardized Residual \\
\hline Cases $<$ Test Value & $.0000000^{\mathrm{b}}$ \\
\hline Cases $>=$ Test Value & 140 \\
\hline Total Cases & 160 \\
\hline Number of Runs & 300 \\
\hline $\mathrm{Z}$ & 148 \\
\hline Asymp. Sig. (2-tailed) & -.271 \\
\hline
\end{tabular}

(Source: Data processed by SPSS 20, 2020)

Run Test results in table 2 above show that the probability level is significant 0.786 because the value $P$ (Asymp. Sig) is greater than the significant level of 0.05 , so it can be concluded that the residual data in this regression model is distributed normally. In other words, the regression model used meets the assumption of normality.

Table-3: Multicolonierity Test

\begin{tabular}{|l|l|l|}
\hline \multirow{2}{*}{ Model } & \multicolumn{2}{|c|}{ Collinearity Statistics } \\
\cline { 2 - 3 } & Tolerance & VIF \\
\hline (Constant) & & \\
Current Earnings & .834 & 1.199 \\
OFC & .824 & 1.213 \\
Accrual & .986 & 1.014 \\
\hline
\end{tabular}

(Source: Data processed by SPSS 20, 2020)
The multicoloniality test results presented in table 4.3 above show that all variables have a tolerance value above 0.10 (Current earnings of 0.834 , operating cash flow 0.824 , and accrual quality of 0.986) with VIF values of under 10 (net income 1,199, operating cash flow 1,213 and accrual quality of $1,014)$ it can be concluded that there is no multicoloniality between variables in this regression model.

Table-4: Heteroscedacity Test (Glejser Test)

\begin{tabular}{|l|l|}
\hline \multicolumn{1}{|c|}{ Model } & Sig. \\
\hline (Constant) & .007 \\
\hline Current Earnings & .814 \\
\hline OFC & .833 \\
\hline Accrual Quality & .073 \\
\hline
\end{tabular}

Dependent Variable: Abs_RES

(Source: Data processed by SPSS 20, 2020)

The output shows that none of the variables have significance below 0.05 . (Current earnings 0.814 $>0.05$, operating cash flow $0.833>0.05$ and accrued quality $0.073>0.05$ ) Therefore, it is stated. That each variable does not experience heteroscedasticity problems.

Table-5: Auto Correlation Test

\begin{tabular}{|c|c|c|r|r|}
\hline \multicolumn{6}{|c|}{ Model Summary $^{\mathbf{b}}$} \\
\hline $\mathrm{R}$ & R Square & Adjusted R Square & Std. Error & Durbin-Watson \\
\hline \multicolumn{7}{|c|}{$.720^{\mathrm{a}}$} & .518 & .513 & .078578 & 2.164 \\
\hline a. & $\begin{array}{l}\text { Predictors: (Constant), Accrual Quality, } \\
\text { Current Earnings, OCF }\end{array}$ \\
\hline
\end{tabular}

(Source: Data processed by SPSS 20, 2020)

Based on table 5 above and based on the analysis results with SPSS, the Durbin-Watson value is $\mathrm{d}=2,164$. It is known that the number of free variables is 3 and the amount of data is 300 , so the value of $\mathrm{dL}$ (fork, $\mathrm{N}=1.79726$ ). Because the value $\mathrm{d}$ is greater than the $\mathrm{dL}$ value, so it was decided that there is no autocorrelation.

Table-6: Test of the Coefficient of Determination $\left(\mathbf{R}^{2}\right)$

\begin{tabular}{|l|c|c|c|c|}
\hline \multicolumn{6}{|c|}{ Model Summary $^{\mathbf{b}}$} \\
\hline Model & $\mathbf{R}$ & $\begin{array}{c}\text { R } \\
\text { Square }\end{array}$ & $\begin{array}{c}\text { Adjusted } \\
\text { R Square }\end{array}$ & $\begin{array}{c}\text { Std. Error of the } \\
\text { Estimate }\end{array}$ \\
\hline 1 & .72 & .518 & .513 & .078578 \\
& 0 & & & \\
\hline \multicolumn{5}{|c|}{ Predictors: (Constant), Accrual Quality, } \\
\hline a. Current Earnings, OCF \\
\hline \multicolumn{4}{|c|}{ b. Dependent Variable: Future Earnings }
\end{tabular}

(Source: Data processed by SPSS 20, 2020)

Based on the regression result, the adjusted $\mathrm{R}$ Square value is 0.513 . This shows that the percentage of future profit can be disclosed through three free variables, namely current earnings, operating cash flow, and accrual quality of $51.3 \%$, while the remaining $48.7 \%$ is presented through several other factors outside the model 
Nanda Thaliana Raditya \& Wiwik Utami., Saudi J Bus Manag Stud, Apr, 2021; 6(4): 125-134

Table-7: Uji F

\begin{tabular}{|r|l|r|r|l|}
\hline \multicolumn{2}{|c|}{ Model } & \multicolumn{1}{l|}{ df } & \multicolumn{1}{c|}{ F } & Sig. \\
\hline & Regression & 3 & 106.123 & $.000^{\mathrm{b}}$ \\
\hline \multirow{2}{*}{1} & Residual & 296 & & \\
\cline { 2 - 5 } & & & & \\
\hline & Total & 299 & & \\
\hline
\end{tabular}

(Source: Data processed by SPSS 20, 2020)

Based on the regression analysis results from table 7 above, it can be known that independent variables together have a significant influence on dependent variables. This can be proven from the value of 106,123 while 2,600 or $106,123>2,600$ (DFL $=k-1$ $=4-1=3, \mathrm{df} 2=\mathrm{n}-\mathrm{k}=300-4=296)$, with a significance of $0.000<0.05$ or $5 \%$, so Ho to perform testing the meaning of this double linear regression is present in the rejection area, meaning that all free variables namely current earnings, operating cash flow and accrual quality have a significant influence on the variable tied future earnings.

Table-8: Uji T

\begin{tabular}{|l|r|r|}
\hline \multicolumn{1}{|c|}{ Model } & \multicolumn{1}{c|}{ t } & \multicolumn{1}{c|}{ Sig. } \\
\hline (Constant) & .377 & .706 \\
Current & 14.563 & .000 \\
Earnings & 3.491 & .001 \\
OCF & -.425 & .671 \\
Accrual Quality & & \\
\hline
\end{tabular}

(Source: Data processed by SPSS 20, 2020)

\section{The Effect of Current Earnings on Future Earnings}

The result of t-test can be concluded that in the variable current earnings $(\mathrm{X} 1)$ as contained in table 8 obtained a total of $14.563>1.968(\mathrm{df}=\mathrm{n}-\mathrm{k}=300-4=$ 296 ) with a significant value of 0.000 i.e. less than the significant level of $0.05(0.000<0.05)$. Meaning H1 is accepted because this study's results have a significant positive effect on future earnings variables.

\section{The Effect of Operating Cash Flows on Future Earnings}

The results of the t-test can be concluded that in the variable operating cash flow (X2), as in table 8 obtained several $3.491>1.968(\mathrm{df}=\mathrm{n}-\mathrm{k}=300-3004=$ 296) with a significant value of 0.001 , i.e., less than the level of significant $0.05(0.001<0.05)$ Meaning $\mathrm{H} 2$ is accepted Because the results of this study have a significant positive effect on future earnings variables.

\section{The Effect of Quality Accrual on Future Earnings}

The result of the t-test can be concluded that in accrual quality variable (X3), as in table 8 obtained several $-0.425<1.968(\mathrm{df}=\mathrm{n}-\mathrm{k}=300-4=296)$ with a significant value of 0.671 , i.e., greater than the significant level of $0.05(0.671>0.05)$ Meaning H3 is rejected, Because the results of this study did not have a significant influence on future earnings variables.
Table-9: Multiple Regression Analysis Test

\begin{tabular}{|l|c|r|}
\hline \multirow{2}{*}{ Model } & \multicolumn{2}{|c|}{$\begin{array}{c}\text { Unstandardized } \\
\text { Coefficients }\end{array}$} \\
\cline { 2 - 3 } & \multicolumn{1}{|c|}{ B } & $\begin{array}{c}\text { Std. } \\
\text { Error }\end{array}$ \\
\hline (Constant) & .003 & .007 \\
Curent Earnings & .697 & .048 \\
\cline { 2 - 3 } OCF t & .141 & .040 \\
\cline { 2 - 3 } Accrual Quality & -.013 & .030 \\
\hline
\end{tabular}

(Source: Data processed by SPSS 20, 2020)

Based on the table above, the multiple linear regression equation can be obtained as follows:

$\mathrm{Y}=0.003+0.697(\mathrm{LA})+0.141($ OCF $)-0.013($ WCA $)$

From the regression results, it can be concluded that:

1. The constant $\mathrm{a}=0.003$ means that if the quality of accruals and operating cash flows are considered constant, the value of future cash flows will increase by 0.003 .

2. The current earnings coefficient is 0.697 in a positive direction. It shows that if the value of future earnings increases by 1 while the other independent variables are fixed, it can increase the value of future earnings by 0.697

3. The cash flow operation coefficient is 0.141 in a positive direction. It shows that if the value of future earnings increases by 1 while the other independent variables are fixed, it can increase the value of future earnings by 0.141

4. The accrual quality coefficient is -0.013 with a negative direction. It shows that if the value of future earnings increases by 1 while the other independent variables are fixed, it can reduce the value of future earnings by -0.013

\section{DISCUSSION}

The Effect of Current Earnings on Future Earnings

The results of this study indicate that current earnings partially have a significant positive effect on future earnings. This research is in line with Wartini [23], Sari and Rahmawati [19], Wijaya and Inda [32], and Yuliafitri [27], which state that earnings affect future earnings. Meanwhile, the results of this study are not in line with the research of Wahyudiono [33], Widyastuti [32], and Palupi Diah [34]. It proves that the higher the company's profits, the more its future profits will be. An increase in net income means that the profit component, namely income and expenses, which can be used to assess the company's ability to achieve a level of profit in the future, will also increase. Vice versa, when net income has decreased, future profits will also decrease. Investors see the increase in net income as an excellent signal to describe the company's prospects and can also be used as a predictor in predicting future earnings, which will then be used as a basis for predicting future stock prices and dividends. Besides, for creditors, increasing profits is good news because it can help creditors assess the company's ability to 
Nanda Thaliana Raditya \& Wiwik Utami., Saudi J Bus Manag Stud, Apr, 2021; 6(4): 125-134

generate sufficient future profits to pay interest costs and pay loan principal. Therefore, an increase in net income is an excellent signal to describe an increase in the company's prospects and can also be used to predict future earnings.

\section{The Effect of Operating Cash Flow on Future Earnings}

This study indicates that operating cash flow partially has a significant positive effect on future earnings. This research is in line with Vina [35], PalupiDiah [34], and Sari and Rahmawati [19], which state that operating cash flow variables have a significant positive effect in predicting future earnings. Meanwhile, the results of this study are not in line with Permatasari's [29] research. It proves that when this year's operating cash flow has increased from the previous year's operating cash flow, the future operating cash flow is also expected to increase. Likewise, when the operating cash flow decreased from the previous year, the operating cash flow also decreased. The cash flow statement information can help investors and creditors assess an entity's ability to generate future profits. Financial reporting aims to provide information that predicts the amount, timing, and uncertainty of future cash flow achievements. Operating cash flow predictions can be made by examining the relationship between items such as sales and net cash flows from operating activities. It is in line with the signal theory, which states that companies provide signals to investors and creditors about the company's operating cash flow to see the prospects for future operating cash flows and see how the company can pay dividends and repay loans to creditors. If the company's operating cash flow outlook improves consistently, it can attract investors and creditors. Therefore, the more the company's operating cash flow increases, its future operating cash flow will also increase, as seen in its comprehensive income statement.

\section{The Effect of Accrual Quality on Future Earnings}

This study indicates that quality accruals partially do not have a significant effect on future earnings. This study is in line with Susi [36], Wijaya and Inda [32], who state that the accrual quality variable does not significantly predict future earnings. In comparison, the results of this study are not in line with research conducted by Chan et al. [37], Parawiyati and Baridwan [38, 40, 41], Nuraini [28]. It proves that the amount of accruals does not affect future earnings. With the quality of the accounting information presented, the company can compare the accruals with its past, present, and future cash flows. Accrual quality is said to be good if it accruals closeness to the company's future cash flows. Accruals' quality has a higher level as a proxy for measurement because accruals are prepared to show more significant economic implications and existing transaction events. Besides predicting future cash flows, accrual quality can also be used to predict future earnings. Because accrual quality indicates company earnings, companies with high accruals show low earnings because company managers tended to use accruals to take earnings management actions.

\section{CONCLUSIONS}

1. Current earnings have a significant positive effect on future earnings. The greater the company's assets are used effectively to generate profits, the greater the ROA shows, the better performance because the return rate is significant.

2. Operating cash flow has a significant positive effect on future earnings. As the company's operating cash flow increases, its future operating cash flow will be increasingly visible in its comprehensive income statement.

3. Accrual quality does not significantly affect future earnings when accrual quality is high if the accrual quality is low. The distortion (deviation) between earnings resulting from accrual accounting is slight than cash flow accounting, resulting in less qualified income.

\section{SUGGESTION}

1) For further researchers

a. It is expected to add other independent variables that affect future income, such as financing cash flows and investment cash flows.

b. It is hoped that a long time and a more significant number of samples from this study can provide good results. The period used in this study is only three years from the 20162018 periods. The addition of a more extended period is expected to provide a clearer picture of the relationship between earnings capabilities, operating cash flows, accrual quality, and future earnings.

c. It is expected that then try to use the accrual quality formula with the Jones Model to compare the results with those using the Dechow and Dichev formula.

2) Potential investors must pay more attention to factors that can predict the company's future

\section{REFERENCES}

1. Ellingga, M. Dan S. (2008). In Irfan Bagus DWI Proyoga. The Effect of Net Income and Accrual Components on Cash Flow in Future Operating Activities (Pg. 5). Thesis, Faculty of Economics and Business, Diponegoro University

2. Prayoga, I. G. (2012). "The Effect of Net earnings and Accrual Components on Operating Cash Flow in the Future" Thesis Semarang: Faculty of Economics and Business. Diponegoro University.

3. Boediono, G. (2005). Earnings Quality: Study of the Effect of Corporate Governance Mechanisms and the Impact of Earnings Management Using Path Analysis. National Symposium on Accounting (SNA) VIII Solo. 
Nanda Thaliana Raditya \& Wiwik Utami., Saudi J Bus Manag Stud, Apr, 2021; 6(4): 125-134

4. Utami, W. (2005). The Effect of Earnings Management on the Cost of Equity Capital. (Studies in Public Companies in the Manufacturing Sector). VIII National Symposium on Accounting, Solo

5. Widyastuti, D.R. (2017). Analysis of Earnings, Operating Cash Flow and Accrual Components in Predicting Future Operating Cash Flows. Essay. Faculty of Economics and Islamic Business. IAIN Surakarta

6. Mulenga, Mwila dan Meena Bhatia. (2017). The Review of Literature on the Role of Earnings, Cash Flows and Accruals in Predicting of Future Cash Flows. Accounting Finance and Research

7. Teruel. (2009). Accruals Quality and Corporate Cash Holdings. Journal compilation Accounting and Finance, 49(1), 95-115.

8. Dechow, P.M., \& Dichev, I.D. (2002). The Quality of Accruals and Earning The Role of Accrual Estimation Errors. The Accounting Review, 77(2002), pp.35-59.

9. Jogiyanto. (2000). Portfolio Theory and Investment Analysis. Second Edition, BPFE UGM, Yogyakarta.

10. Jogiyanto Hartono.(2013). Investment Theory and Analysis. Eighth Edition. Yogyakarta; BPFE.

11. Jensen, Michael C. And W.H. Meckling. (1976). Theory of the Firm: Managerial Behavior, Agency Cost and Ownership Structure. Journal of Financial Economics 3. Hal. 305-360

12. Hery. (2012). Financial Statement Analysis. Jakarta: Bumi Aksara Hikmah, N.,

13. Santoso, I. (2009). Intermediate Financial Accounting Book Two. Bandung: Refika Aditama

14. Subramanyam, K. R., \& John, J. W. (2014). Financial Statement Analysis. Translator for Dewi Y. Jakarta: Salemba Empat.

15. Rispayanto, S. (2013). The Effect of Gross Profit, Operating Earnings, Net Earnings and Operating Cash Flow in Predicting Future Operating Cash Flows (Empirical Study of Manufacturing Companies Listed on the IDX). Journal of Accounting, 1(3).

16. Pernamasari, R. (2018). Implementation of Good Corporate Governance and Earning Management on Debt Costs in State-Owned Companies CGPI Listing 2010 - 2012. Profita Journal. Vol. 11. No. 1. April. 2018, 68

17. Dechow, P., Ge, W., \& Schrand, C. (2010). "Understanding Earnings Quality: A Review of Proxies, Their Determinants and Their Consequence". Journal of Accounting and Economic, 50 (2) \& (3), 344-401

18. Francis, Jennifer, et al. 2004. Cost of equity and earnings attributes. The Accounting Review, 79 (4): 967 - 1010.

19. Sari, D. P., \& Rahmawati, A. (2007). The Ability of Earnings and Cash Flow in Predicting Future Earnings and Cash Flow in Manufacturing Companies on the Jakarta Stock Exchange Vol. 10
No. 1, March 2007. Journal of Media Economics \& Information Technology, 32-47

20. McNichols, M. (2002). Discussion of "The Quality of Accruals and Earnings: The Role of Accrual Estimation Errors". The Accounting Review, 77, 61-69.

21. Jones, J.J. (1991). Earning Management during Import Relief Investigations. Journal of Accounting Research 29 No. 2: 193-228.

22. Kieso, Donald E., Jerry J, Weygant \& Terry D. Warfield. (2015). Intermediate Accounting Volume 1 IFRS Edition. United States of America

23. Wartini. (2013). The Influence of Gross Earnings, Operating Earnings and Net Earnings in Predicting Cash Flow of Operating Activities in the Future Empirical Study of Manufacturing Companies Engaged in the Basic Industry and Chemical Sectors on the Indonesia Stock Exchange Period. King Ali Hajj Maritime University

24. Yuwana, V. (2014). Analysis of the Ability of Operating Earnings and Cash Flow in Predicting Future Operating Cash Flows. Business Accounting Review, 2(1), 1-10.

25. Arnedo, L., Fermin, L., Santiago, S. (2012). The Role of Accounting Accruals for the Prediction of Future Cash Flows: Evidence from Spain. Journal of Spanish Economic Association. Vol. 3: 499-520, ISSN 1869-4195.

26. Apriliana, F. (2014). Capability of Net Earnings, Historical Operating Cash Flow and Accrual Components in Predicting Cash Flows for Operating Activities in the Future. Thesis: Faculty of Economics and Business. Diponegoro University. Semarang

27. Yuliafitri, I. (2011). Analysis of Factors Affecting Profits and Future "Cash Flow" In Go Public Companies. Journal of Investments, 7(1), 14-30

28. Nuraina, E. (2011). "Earnings, operating cash flow and accruals as determinants of future operating earnings ". Journal of Management Dynamics, 2(1), 52-69.

29. Permatasari, D. P. (2011). Earnings and Cash Flow Capability in Predicting Future Earnings at Food \& Beverages Companies Listed on the Indonesia Stock Exchange. Thesis, East Java "Veteran" National Development University.

30. Pardede, R., \& Manurung, R. (2014). Path Analysis Theory and Application in Business Research. Jakarta: Rineka Cipta

31. Sekaran, U., \& Bougie, R. (2017). Research Methods for Business, Ed. 6, Book 1. Jakarta : Salemba Empat

32. Wijaya, R. M. (2014). Faktor-Faktor Yang Mempengaruhi Kemauan Untuk Membayar Pajak Wajib Pajak Orang Pribadi Yang Melakukan Pekerjaan Bebas (Studi Kasus Pada Kpp Pratama Karanganyar) (Doctoral dissertation, Universitas Muhammadiyah Surakarta).

33. Wahyudiono, B. (2014). Easy to Read Financial Statements. Jakarta: Achieve Success. 
34. Palupi, D. A. (2009). Aplikasi Penanganan Keluhan Pelayanan Teknologi Informasi Berbasis Metode Highest Prority In First Server Study Kasus Pada PT. Telkom (Doctoral dissertation, Universitas Mercu Buana).

35. Subramanyam, K. R., \& John, J. W. (2014). Financial Statement Analysis. Translator for Dewi Y. Jakarta: Salemba Empat.

36. Susi, T., Hofer, C., Argentero, G., Leuthner, G. T., Pennycook, T. J., Mangler, C., ... \& Kotakoski, J. (2016). Isotope analysis in the transmission electron microscope. Nature communications, 7(1), 1-10.

37. Chan. (2004), Analytical Method Validation and Instrument Performance Verifaction. Canada : John
Willey \& Sons

38. Parawiyati dan Baridwan. (1998). "Earnings and cash flow ability in predicting earnings and cash flow of go public companies in Indonesia ". JRAI vol.1. Number 1.

39. Indonesian Accounting Association. PSAK No. 1 About Financial Statements - revised edition. (2018). Publisher of Financial Accounting Standards Board: PT. Raja Grafindo.

40. Parawiyati dan Baridwan. (1998). "Earnings and cash flow ability in predicting earnings and cash flow of go public companies in Indonesia". JRAI vol.1. Number 1.

41. Wiwin Yadiarti. (2010). An Introduction to Accounting Theory, Kencana, Jakarta. 